\title{
PERFORMANCE OF AXIALLY LOADED TAPERED CONCRETE-FILLED STEEL COMPOSITE SLENDER COLUMNS
}

\author{
Alireza BAHRAMI, Wan Hamidon WAN BADARUZZAMAN, Siti Aminah OSMAN \\ Department of Civil and Structural Engineering, Universiti Kebangsaan Malaysia, \\ Bangi, Selangor, Malaysia
}

Received 11 Nov. 2011; accepted 22 Dec. 2011

\begin{abstract}
This paper focuses on the performance of a special kind of tapered composite columns, namely tapered concrete-filled steel composite (TCFSC) slender columns, under axial loading. These efficient TCFSC columns are formed by the increase of the mid-height depth and width of straight concrete-filled steel composite (CFSC) slender columns, that is, by the enhancement of the tapered angle (from $0^{\circ}$ to $2.75^{\circ}$ ) of the tapered composite columns from their top and bottom to their mid-height. To investigate the performance of the columns, finite element software LUSAS is employed to carry out the nonlinear analyses. Comparisons of the nonlinear finite element results with the existing experimental results uncover the reasonable accuracy of the proposed modelling. Nonlinear analyses are extensively performed and developed to study effects of different variables such as various tapered angles, steel wall thicknesses, concrete compressive strengths, and steel yield stresses on the performance of the columns. It is concluded that increasing each of these variables considerably enhances the ultimate axial load capacity. Also, enhancement of the tapered angle and/or steel wall thickness significantly improves the ductility. Moreover, confinement effect of the steel wall on the performance of the columns is evaluated. Failure modes of the columns are also presented.
\end{abstract}

Keywords: tapered composite slender column; finite element analysis; ultimate load capacity; ductility; concrete compressive strength; steel yield stress.

Reference to this paper should be made as follows: Bahrami, A.; Wan Badaruzzaman, W. H.; Osman, S. A. 2013. Performance of axially loaded tapered concrete-filled steel composite slender columns, Journal of Civil Engineering and Management 19(5): 705-717. http://dx.doi.org/10.3846/13923730.2013.799094.

\section{Introduction}

The composite action between the main materials of concrete-filled steel composite (CFSC) columns, steel and concrete, has ideally combined the distinct advantages of the both materials and resulted in high strength, large ductility, and high stiffness. These advantages have demonstrated the priority of the CFSC columns over steel and reinforced concrete columns and have also led to their increasing use in modern structural engineering applications worldwide. Research on the behaviour of the CFSC columns has been widely performed during the past years. Introduction of an empirical reduction factor to account for the effect of in-filled concrete prism size and the concrete strength class was made by Bradford (1996) to evaluate the compressive strength of concrete. Brauns (1999) analysed stress state in concrete-filled steel columns. An analytical model using an effective width principle was presented by Shanmugam et al. (2002) to predict the behaviour and load carrying capacity of concrete-filled thin-walled steel box columns. Han and Yang (2003) investigated thin-walled steel rectangular hollow section columns filled with concrete under long-term sustained loads. Tests on concrete-filled high-strength steel box columns were conducted by Mursi and Uy (2004). Zeghiche and Chaoui (2005) tested concrete-filled steel tubular columns, where the parameters were the column slenderness, load eccentricity, and concrete compressive strength. Effects of the shape of the stainless steel tube, plate thickness, and concrete strength on the behaviour of concrete-filled cold-formed high-strength stainless steel tube columns were assessed by Young and Ellobody (2006). An experimental and analytical investigation on the behaviour of eccentrically loaded high-strength rectangular concrete-filled steel tubular

Corresponding author: Alireza Bahrami

E-mail: bahrami_a_r@yahoo.com 
columns was performed by Liu (2006). Ellobody (2007) studied nonlinear behaviour of concrete-filled high-strength stainless steel stiffened slender square and rectangular tubes. Twenty-six high-strength concrete-filled slender rectangular hollow section tubes were experimentally investigated under the combined actions of axial compression and bending moment by Zhang and Guo (2007). Study on the use of thinwalled hollow structural steel columns in-filled with very high-strength self-consolidating concrete was presented by Yu et al. (2008). Concrete-filled stiffened thin-walled steel tubular columns were evaluated under axial compression by Tao et al. (2009). Uenaka et al. (2010) tested concrete-filled double skin circular columns under compression. Muciaccia et al. (2011) conducted an experimental and analytical investigation on concrete-filled tubes with critical lengths ranging from $131 \mathrm{~cm}$ to $467 \mathrm{~cm}$. Nonlinear behaviour of concrete-filled steel composite columns was investigated by Bahrami et al. (2011) to study and develop different shapes and number of cold-formed steel sheeting stiffeners with various thicknesses of coldformed steel sheets and also assess their effects on the behaviour of the columns.

Tapered concrete-filled steel composite columns can be used for high and low rise buildings because of their large load carrying capacity and high ductility. Han et al. (2010) performed an experimental study on inclined, tapered, and straight-tapered-straight concrete-filled steel tubular stub columns. The tapered angle (from the bottom to the top) and cross-sectional type (circular and square) were the main variables of their tapered stub columns. The section areas of their circular and square tapered stub columns were reduced gradually from the bottom to the top owing to the tapered angle. The length of their stub columns was $600 \mathrm{~mm}$. Also, Han et al. (2011) conducted tests on straight, inclined, and tapered stainless steelconcrete-carbon steel double-skin tubular stub columns. The main parameters of their tapered stub columns were the sectional type (circular, square, round-end rectangular, and elliptical) and the hollow ratio of the composite section (from 0.5 to 0.75 ). Their tapered stub columns were double skin with the lengths of $660 \mathrm{~mm}$ and $720 \mathrm{~mm}$. The tapered angle of the columns tested by Han et al. (2011) was similar to that of the tapered columns investigated by Han et al. (2010). In other words, the tapered angle increased from the bottom to the top of the columns so that the section areas were reduced gradually from the bottom to the top.

Tapered concrete-filled steel composite (TCFSC) slender columns investigated in this paper are a special kind of tapered composite columns and completely different from those tapered composite stub columns available in the literature from two different important aspects: first, the TCFSC columns of this study are slender, while the above-mentioned studied tapered composite columns are stub; second, the tapered angle of the TCFSC slender columns in this study increases from their top and bottom to their mid-height, which is different from the common tapered angle (from the bottom to the top). No studies could be found in the literature on these special TCFSC slender columns.

The present study is concerned with the performance of the axially loaded TCFSC slender columns. In order to verify the modelling, nonlinear finite element results are compared with the corresponding experimental results presented by Liu (2006). Nonlinear finite element analyses are carried out and developed to study the performance of the columns with different tapered angles (from $0^{\circ}$ to $2.75^{\circ}$ ), steel wall thicknesses (from $3 \mathrm{~mm}$ to $4 \mathrm{~mm}$ ), concrete compressive strengths (from $30 \mathrm{MPa}$ to $60 \mathrm{MPa}$ ), and steel yield stresses (from $250 \mathrm{MPa}$ to $495 \mathrm{MPa}$ ). Effects of various tapered angles with different steel wall thicknesses on the ultimate axial load capacity and ductility of the columns are also evaluated. Moreover, effects of different concrete compressive strengths and steel yield stresses on the ultimate axial load capacity are examined. In addition, confinement effect of the steel wall on the performance of the columns is assessed. Failure modes of the columns are presented, as well.

\section{Constitutive models}

Because the columns are made of steel and concrete, modelling of these materials is an important part in the constitution of numerical analysis, which is described in the following sections.

\subsection{Steel}

Modelling of steel was carried out as an elasticperfectly plastic material in both tension and compression herein. The stress-strain curve for steel is shown in Figure 1. The yield stress and modulus of elasticity of steel have been considered as $495 \mathrm{MPa}$ and 206,000 MPa respectively, which are the same as those of the corresponding experiments. Von Mises yield criterion, an associated flow rule, and isotropic hardening were utilised in the nonlinear material model.

\subsection{Concrete}

The compressive strength and modulus of elasticity of concrete have been taken as $60 \mathrm{MPa}$ and $39,000 \mathrm{MPa}$ respectively, which are identical to those of the corresponding experiments. Figure 2 shows the 


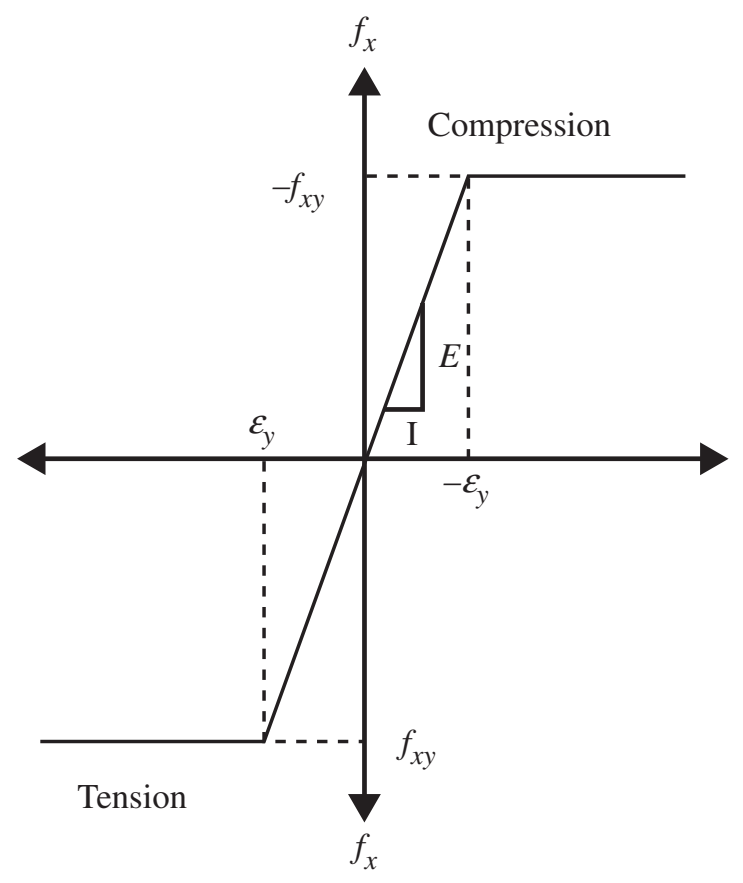

Fig. 1. Stress-strain curve for steel

equivalent uniaxial stress-strain curves used for concrete herein (Ellobody, Young 2006a, b). The unconfined concrete cylinder compressive strength $f_{c}$ is $0.8 f_{c u}$ in which $f_{c u}$ is the unconfined concrete cube compressive strength. In accordance with $\mathrm{Hu}$ et al. (2005), the corresponding unconfined strain $\varepsilon_{c}$ is usually around the range of $0.002-0.003$. They considered $\varepsilon_{c}$ as 0.002 . The same value for $\varepsilon_{c}$ has been also taken in the analyses of this study. When concrete is under laterally confining pressure, the confined compressive strength $f_{\mathrm{cc}}$ and the corresponding confined strain $\varepsilon_{c c}$ are much greater than those of unconfined concrete.

Equations (1) and (2) have been used to respectively obtain the confined concrete compressive

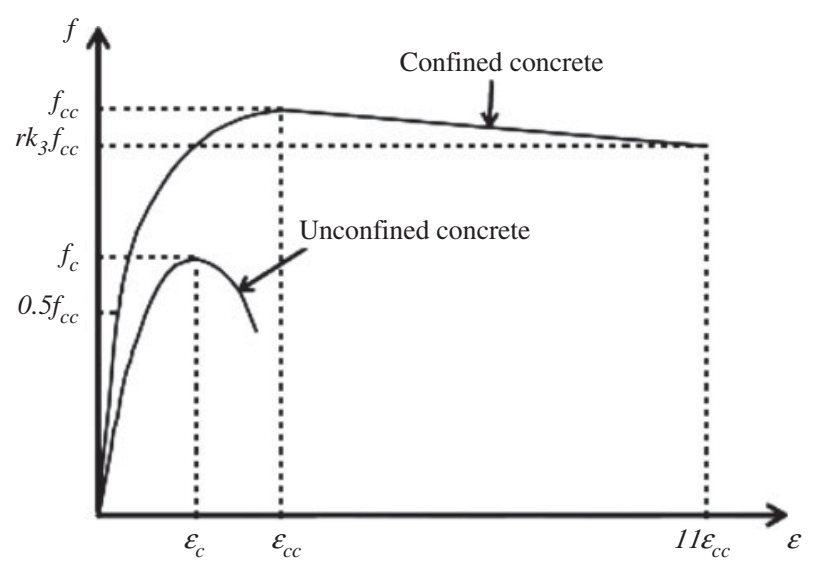

Fig. 2. Equivalent uniaxial stress-strain curves for concrete (Ellobody, Young 2006b) strength $f_{c c}$ and the corresponding confined stain $\varepsilon_{c c}$ (Mander et al. 1988):

$$
\begin{gathered}
f_{c c}=f_{c}+k_{1} f_{1} ; \\
\varepsilon_{c c}=\varepsilon_{c}\left(1+k_{2} \frac{f_{1}}{f_{c}}\right),
\end{gathered}
$$

in which $f_{1}$ is the lateral confining pressure of the steel wall on the concrete core. The approximate value of $f_{1}$ can be determined by interpolating the values reported by $\mathrm{Hu}$ et al. (2003). The factors of $k_{1}$ and $k_{2}$ have been taken as 4.1 and 20.5, respectively (Richart et al. 1928). Since $f_{1}, k_{1}$ and $k_{2}$ are known $f_{c c}$ and $\varepsilon_{\mathrm{cc}}$ can be calculated by the use of Eqns (1) and (2). In accordance with Figure 2, the equivalent uniaxial stress-strain curve for confined concrete has three parts that are needed to be defined. The first part consists of the initially assumed elastic range to the proportional limit stress. The value of the proportional limit stress has been adopted as $0.5 f_{c c}$ (Hu et al. 2003). The empirical Eqn. (3) has been used to determine the initial Young's modulus of confined concrete $E_{c c}$ (ACI 1999). The Poisson's ratio $v_{c c}$ of confined concrete has been considered as 0.2 .

$$
E_{c c}=4700 \sqrt{f_{c c}} \mathrm{MPa} .
$$

The second part includes the nonlinear portion, which starts from the proportional limit stress $0.5 f_{c c}$ to the confined concrete strength $f_{c c}$. The common Eqn. (4) can be used to determine this part (Saenz 1964). The values of uniaxial stress $f$ and strain $\varepsilon$ are the unknowns of the equation that define this part of the curve. The strain values $\varepsilon$ have been considered between the proportional strain $\left(0.5 f_{c c} / E_{c c}\right)$, and the confined strain $\varepsilon_{c c}$ which corresponds to the confined concrete strength. Eqn. (4) can be used to determine the stress values $f$ by assuming the strain values $\varepsilon$ :

$$
f=\frac{E_{c c} \varepsilon}{1+\left(R+R_{E}-2\right)\left(\frac{\varepsilon}{\varepsilon_{c c}}\right)-(2 R-1)\left(\frac{\varepsilon}{\varepsilon_{c c}}\right)^{2}+R\left(\frac{\varepsilon}{\varepsilon_{c c}}\right)^{3}},
$$

in which $R_{E}$ and $R$ are:

$$
\begin{gathered}
R_{E}=\frac{E_{c c} \varepsilon_{c c}}{f_{c c}} ; \\
R=\frac{R_{E}\left(R_{\sigma}-1\right)}{\left(R_{\varepsilon}-1\right)^{2}}-\frac{1}{R_{\varepsilon}} .
\end{gathered}
$$

The constants $R_{\varepsilon}$ and $R_{\sigma}$ have been adopted as 4 in this study (Hu, Schnobrich 1989). The third part of the curve is the descending part which is between $f_{c c}$ and $r k_{3} f_{c c}$ with the corresponding strain of $11 \varepsilon_{c c}$. The reduction factor is $k_{3}$, dependent on the $H / t$ ratio. Empirical equations proposed by $\mathrm{Hu}$ et al. (2003) can be used to determine the approximate value of $k_{3}$. To consider the effect of different concrete strengths, the 
reduction factor $r$ was introduced by Ellobody et al. (2006) based on the experimental study done by Giakoumelis and Lam (2004). The value of $r$ has been adopted as 1.0 for concrete with cube strength $f_{c u}$ equal to $30 \mathrm{MPa}$, and as 0.5 for concrete with $f_{c u}$ greater than or equal to $100 \mathrm{MPa}$ (Tomii 1991; Mursi, Uy 2003). The value of $r$ for concrete cube strength between $30 \mathrm{MPa}$ and $100 \mathrm{MPa}$ has been calculated by the use of linear interpolation.

\section{Description of nonlinear finite element analysis}

\subsection{General}

Nonlinear finite element analyses were performed in this study by the use of the finite element software LUSAS Version 14. A CFSC column, experimentally tested in the past by Liu (2006) has been chosen in this paper for the nonlinear finite element analyses. The column is $2.6 \mathrm{~m}$ long with a steel wall thickness of $4 \mathrm{~mm}$ and a cross section of $150 \times 100 \mathrm{~mm}$. Figure 3(a) illustrates the geometry of the column including its concrete core and steel wall.

In addition to material constitutive models of steel and concrete, there are other important parameters in the CFSC columns, which were needed to be appropriately modelled in order to accurately simulate the actual behaviour of the columns herein. These parameters consist of finite element type, mesh, boundary conditions, load application, and concretesteel wall interface which are described in the following section.

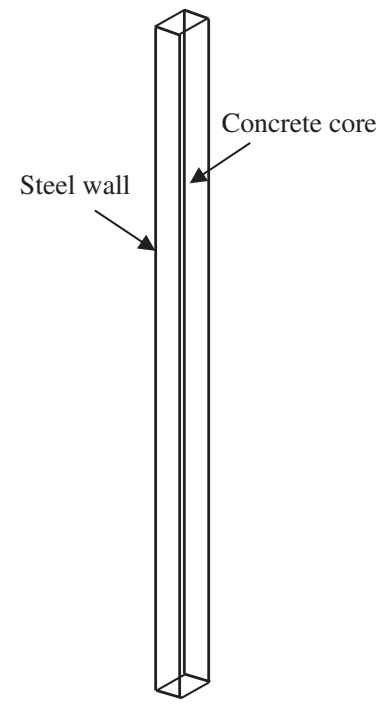

a

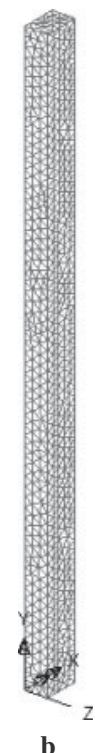

b
Fig. 3. Typical CFSC slender column in this study: (a) geometry, (b) finite element mesh

\subsection{Finite element type, mesh, boundary conditions, load application, and concrete-steel wall interface}

Modelling of the steel wall was done by the use of the 6-noded triangular shell element, TSL6. This is a thin, doubly curved, isoparametric element that can be used to model three-dimensional structures. This element can accommodate generally curved geometry with varying thickness and anisotropic and composite material properties (Finite Element Analysis Ltd. 2006). The element formulation takes account of both membrane and flexural deformations. Modelling of the concrete core was carried out by the use of the 10-noded tetrahedral element, TH10. This is a threedimensional isoparametric solid continuum element, capable of modelling curved boundaries. This element is a standard volume element of the finite element software LUSAS.

Different mesh sizes were tried to determine a suitable finite element mesh size for the modelling to obtain exact results. As a consequence, the nonlinear finite element analysis based on the mesh size corresponding to 7538 elements was uncovered to predict the performance of the columns with very good accuracy. A typical finite element mesh used in this study is shown in Figure 3(b).

Because the pin-pin boundary conditions were considered in the corresponding experiments carried out by Liu (2006), these conditions have been also applied in the finite element modelling herein. Therefore, the rotations in the $\mathrm{X}, \mathrm{Y}$, and $\mathrm{Z}$ directions for the top and bottom surfaces of the columns were set to be free. Also, the displacements in the $\mathrm{X}$ and $\mathrm{Z}$ directions for the bottom and top surfaces were restrained. On the other hand, the displacement in the Y direction for the bottom surface was restrained, while the one for the top surface, in the direction of the applied load and where the load is applied was set to be free.

Loading of the columns in the experiments was eccentric about the major axis with eccentricities of $15 \mathrm{~mm}, 45 \mathrm{~mm}$, and $60 \mathrm{~mm}$, which has been accurately simulated by incremental displacement load with an initial increment of $1 \mathrm{~mm}$ applied in the negative $\mathrm{Y}$ direction with the same eccentricities to the columns.

The contact between the concrete core and the steel wall was modelled by slidelines in this study. The slidelines are attributes which can be used to model contact surfaces in the finite element software LUSAS (Finite Element Analysis Ltd. 2006). They are advantageous when there is no prior knowledge of the contact point. The slideline contact facility is naturally nonlinear and was used in the nonlinear analyses. To construct the contact between two surfaces, the concrete core and the steel wall, the slave and master surfaces should be selected correctly. If a smaller surface is in contact with a larger surface, the best selection for the slave surface is the smaller surface. If this point cannot be distinguished, the master surface 
should be selected as the body which has higher stiffness. It should be noted that in order to choose the slave and master surfaces, the stiffness of the structure should be taken into account and not just the material. Although, the steel material is stiffer than the concrete material, the steel wall may be less stiff than the volume of the concrete core in this study. Consequently, the concrete core surface was selected as the master surface while the steel wall surface was selected as the slave surface herein. Dabaon et al. (2009) also adopted the same process as mentioned above in choosing master and slave surfaces in their study. The slidelines allow the definition of properties, such as friction coefficient. The friction between two surfaces, the concrete core and the steel wall, is maintained so that they can remain in contact. The Coulomb friction coefficient in the slidelines was taken as 0.25 . The slidelines allow the concrete core and the steel wall to slide or separate without penetrating each other.

\section{Modelling verification}

Three comparisons were carried out between the results of the finite element modelling and the experiments done by Liu (2006) to reveal the accuracy of the modelling herein. Figure 4 shows that the curves from the nonlinear finite element analyses agree well with those from the experiments. In accordance with the figure, the obtained ultimate load capacities from the nonlinear finite element analyses of the columns with the eccentricities $(e)$ of $15 \mathrm{~mm}, 45 \mathrm{~mm}$, and $60 \mathrm{~mm}$ are respectively $1106 \mathrm{kN}, 695 \mathrm{kN}$, and $601 \mathrm{kN}$, while those from the experiments of the same columns are respectively $1130 \mathrm{kN}, 711 \mathrm{kN}$, and $617 \mathrm{kN}$. Accordingly, the differences between the ultimate load capacities of the columns resulted by the nonlinear finite element analyses and the experiments are only $2.1 \%, 2.3 \%$, and $2.6 \%$. These small differences illustrate the accuracy of the modelling. As a result, the proposed three-dimensional finite element modelling is reasonably accurate to predict the performance of the columns in this study.

\section{Numerical analysis}

Because it was uncovered that the proposed finite element modelling in this study is accurate to investigate the performance of the columns, the method was utilised for the nonlinear analysis of the columns with the same length and cross section as the experimentally tested columns by Liu (2006), but with tapered angles under axial loading. Since CFSC slender columns generally fail due to overall buckling, the mid-height of the columns is more prone to higher stresses. Consequently, if the mid-height cross section of the CFSC slender columns, larger than those at the two ends is adopted, overall buckling of the columns
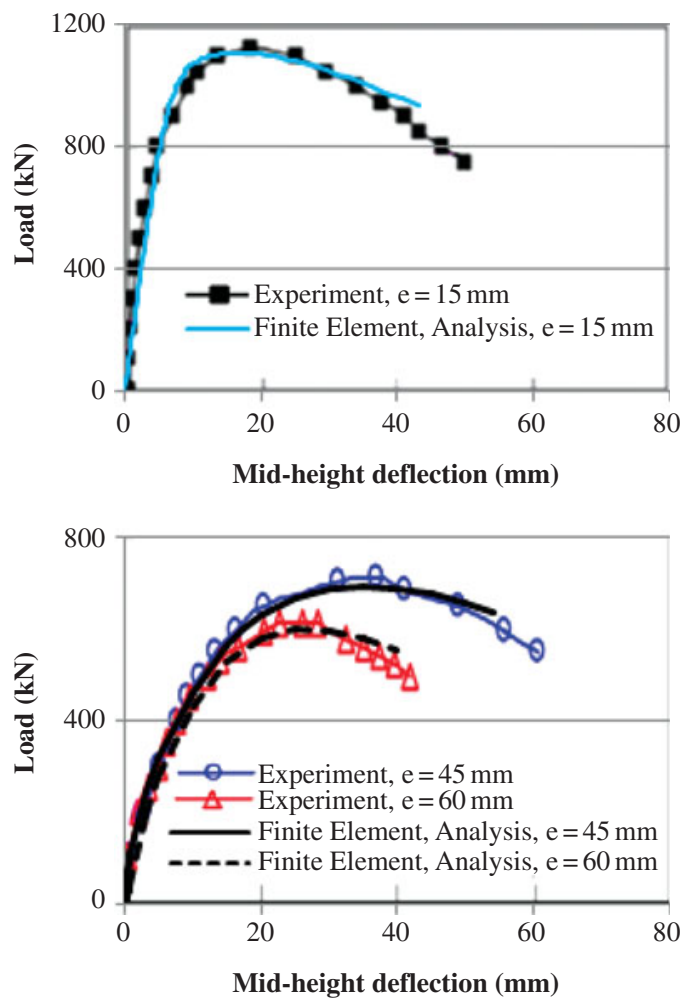

Fig. 4. Load versus mid-height deflection curves for the columns

will be postponed, and it is expected to lead to greater ultimate load capacity and higher ductility of the columns. Because of this point, mid-height cross section larger than those at the two ends for the CFSC slender columns has been adopted, which has formed a special tapered angle in this study. A typical geometry of the TCFSC slender columns which was accurately modelled on the basis of the above modelling specifications is illustrated in Figure 5(a). $H_{m}, B_{m}$, and $\theta$ imply the mid-height depth and width, and the tapered angle of the columns, respectively. A typical finite element mesh of the TCFSC slender columns is also depicted in Figure 5(b). Obtained results from the nonlinear finite element analyses are presented in the following sections.

\section{Results and discussion}

Table 1 summarises the specifications and ultimate axial load capacities of the TCFSC slender columns, which were analysed by the nonlinear finite element method in this study. $C$ in the column designations represents the columns and the following four numbers in the labels are utilised to differ the columns with various $H_{m} \times B_{m} \times t(\mathrm{~mm})$, tapered angles $(\theta)$, steel yield stresses $f_{y}(\mathrm{MPa})$, and concrete compressive strengths $f_{c}(\mathrm{MPa})$. These different parameters $\left(H_{m} \times B_{m} \times t, \theta, f_{y}\right.$, and $\left.f_{c}\right)$ have been considered in this investigation to widely evaluate the performance of the TCFSC columns under various conditions. The 


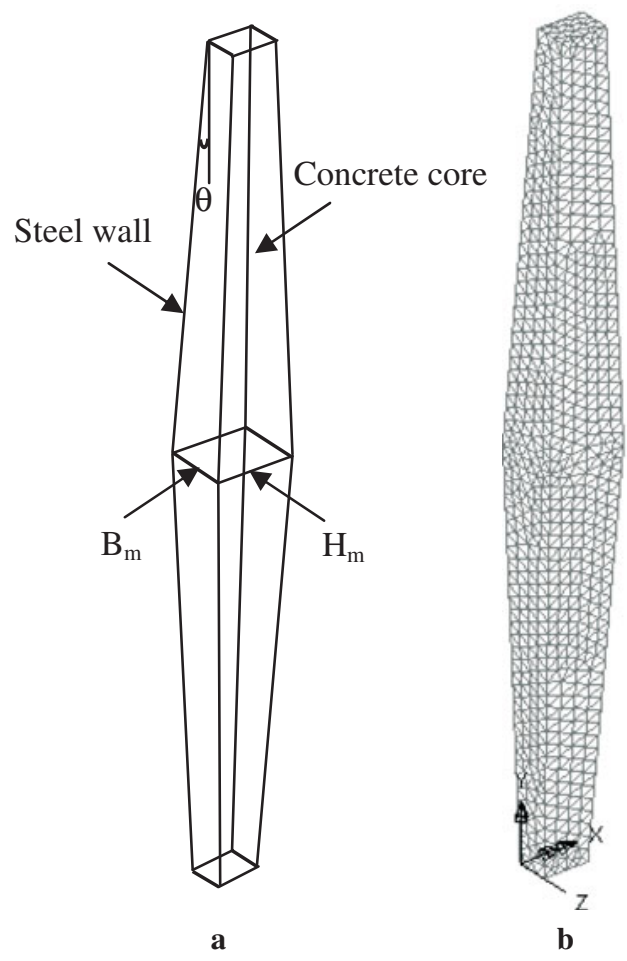

Fig. 5. Typical TCFSC slender column in this study $(\theta=$ $2.20^{\circ}$ ): (a) geometry, (b) finite element mesh

corresponding axial load-normalised axial shortening plots of the obtained results in Table 1 are also illustrated in the following sections.

Moreover, effects of the parameters on the ultimate axial load capacity and ductility of the TCFSC columns are discussed in the sections below.

\subsection{Effect of steel wall thickness on ultimate axial load capacity}

The effect of different steel wall thicknesses $(t=3 \mathrm{~mm}$, $3.5 \mathrm{~mm}$, and $4 \mathrm{~mm})$ with various tapered angles $\left(\theta=0^{\circ}\right.$, $0.55^{\circ}, 1.10^{\circ}, 1.65^{\circ}, 2.20^{\circ}$, and $2.75^{\circ}$ ) on the ultimate axial load capacity of the TCFSC columns is depicted in Figure 6, and its corresponding values are also listed in Table 1. According to the figure and the table, the ultimate axial load capacity of the columns is considerably influenced by change of the steel wall thickness. Increasing the steel wall thickness improves the ultimate axial load capacity. The improvement of the ultimate axial load capacity can be attributed to the fact that as a thicker steel wall is used more confinement effect is provided on the concrete core by the steel wall, which finally results in the higher ultimate axial load capacity. For instance, in the case of the column C6-1495-60 with the steel wall thickness of $3 \mathrm{~mm}$ the ultimate axial load capacity is $1102 \mathrm{kN}$, which is increased to $1199 \mathrm{kN}$ by the use of the column C4-1-495-60 with the steel wall thickness of $4 \mathrm{~mm}$, an enhancement of $8.8 \%$.

\subsection{Effect of tapered angle on ultimate axial load capacity}

Figure 7 indicates the effect of various tapered angles $\left(\theta=0^{\circ}, 0.55^{\circ}, 1.10^{\circ}, 1.65^{\circ}, 2.20^{\circ}\right.$, and $\left.2.75^{\circ}\right)$ with different steel wall thicknesses $(t=3 \mathrm{~mm}, 3.5 \mathrm{~mm}$, and $4 \mathrm{~mm}$ ) on the ultimate axial load capacity of the TCFSC columns. These 5 steps of the tapered angle increase $\left(0^{\circ}-0.55^{\circ}, 0.55^{\circ}-1.10^{\circ}, 1.10^{\circ}-1.65^{\circ}, 1.65^{\circ}-\right.$ $2.20^{\circ}$, and $2.20^{\circ}-2.75^{\circ}$ ) have been adopted in this study to extensively investigate the effect of this special kind of the tapered angle on the performance of the columns. As can be seen from the figure and the table, change of the tapered angle has a noticeable effect on the ultimate axial load capacity of the columns. By the enhancement of the tapered angle from $0^{\circ}$ to $2.75^{\circ}$, the ultimate axial load capacity of the columns is increased. Because increasing the tapered angle of the slender columns increases the dimensions of $H_{m}$ and $B_{m}$ at their mid-height which leads to the delay of their overall buckling and finally the enhancement of their ultimate axial load capacity. For example, the ultimate axial load capacity of the column C2-0-495-60 with $\theta=0^{\circ}$ is $1092 \mathrm{kN}$, which is improved to $1343 \mathrm{kN}$ of the column C17-5-495-60 with $\theta=2.75^{\circ}$, an improvement of $23 \%$.

In addition, the increased percentage of the ultimate axial load capacity of the columns due to the increase of the tapered angle is not significant when the tapered angle is greater than $2.20^{\circ}$. As an example, the increase of the tapered angle of the column C3-0-49560 from $0^{\circ}$ to $0.55^{\circ}$ of C6-1-495-60, $1.10^{\circ}$ of C9-2-495$60,1.65^{\circ}$ of $\mathrm{C} 12-3-495-60$, and $2.20^{\circ}$ of C15-4-495-60 enhances the ultimate axial load capacity of the columns from $1005 \mathrm{kN}$ to $1102 \mathrm{kN}, 1162 \mathrm{kN}, 1214 \mathrm{kN}$, and $1278 \mathrm{kN}$, respectively. This issue reveals 9.7, 5.4, 4.5 , and $5.3 \%$ enhancement of the ultimate axial load capacity respectively in each step of the above angle increases. On the other hand, enhancing the tapered angle from $2.20^{\circ}$ (C15-4-495-60) to $2.75^{\circ}$ (C18-5-49560) improves the ultimate axial load capacity from $1278 \mathrm{kN}$ to $1289 \mathrm{kN}$, a slight increase of $0.9 \%$.

\subsection{Effects of tapered angle and steel wall thickness on ductility}

In order to examine the effects of the tapered angle and the steel wall thickness on the ductility of the columns, the following ductility index is used in this study (Lin, Tsai 2001):

$$
D I=\frac{\varepsilon_{85 \%}}{\varepsilon_{y}}
$$

where $\varepsilon_{85 \%}$ is the nominal axial shortening $(\Delta / L)$ of the columns corresponding to the load which drops to $85 \%$ of the ultimate axial load capacity and $\varepsilon_{y}$ is $\varepsilon_{75 \%} l$ 0.75 in which $\varepsilon_{75 \%}$ is the nominal axial shortening of the columns corresponding to the load that obtains $75 \%$ of the ultimate axial load capacity. The values of $\varepsilon_{85 \%}$ and $\varepsilon_{y}$ can be taken from Figure 6 . 
Table 1. Specifications and ultimate axial load capacities $\left(N_{u}\right)$ of the columns

\begin{tabular}{|c|c|c|c|c|c|c|}
\hline Number & Column label & $H_{m} \times B_{m} \times t(\mathrm{~mm})$ & Tapered angle $\left(\theta^{\circ}\right)$ & $f_{y}(\mathrm{MPa})$ & $f_{c}(\mathrm{MPa})$ & $N_{u}(\mathrm{kN})$ \\
\hline 1 & C1-0-495-60 & $150 \times 100 \times 4$ & 0 & 495 & 60 & 1174 \\
\hline 2 & C2-0-495-60 & $150 \times 100 \times 3.5$ & 0 & 495 & 60 & 1092 \\
\hline 3 & C3-0-495-60 & $150 \times 100 \times 3$ & 0 & 495 & 60 & 1005 \\
\hline 4 & C4-1-495-60 & $175 \times 125 \times 4$ & 0.55 & 495 & 60 & 1199 \\
\hline 5 & C5-1-495-60 & $175 \times 125 \times 3.5$ & 0.55 & 495 & 60 & 1152 \\
\hline 6 & C6-1-495-60 & $175 \times 125 \times 3$ & 0.55 & 495 & 60 & 1102 \\
\hline 7 & C7-2-495-60 & $200 \times 150 \times 4$ & 1.10 & 495 & 60 & 1260 \\
\hline 8 & C8-2-495-60 & $200 \times 150 \times 3.5$ & 1.10 & 495 & 60 & 1213 \\
\hline 9 & C9-2-495-60 & $200 \times 150 \times 3$ & 1.10 & 495 & 60 & 1162 \\
\hline 10 & C10-3-495-60 & $225 \times 175 \times 4$ & 1.65 & 495 & 60 & 1316 \\
\hline 11 & C11-3-495-60 & $225 \times 175 \times 3.5$ & 1.65 & 495 & 60 & 1267 \\
\hline 12 & C12-3-495-60 & $225 \times 175 \times 3$ & 1.65 & 495 & 60 & 1214 \\
\hline 13 & C13-4-495-60 & $250 \times 200 \times 4$ & 2.20 & 495 & 60 & 1387 \\
\hline 14 & C14-4-495-60 & $250 \times 200 \times 3.5$ & 2.20 & 495 & 60 & 1334 \\
\hline 15 & C15-4-495-60 & $250 \times 200 \times 3$ & 2.20 & 495 & 60 & 1278 \\
\hline 16 & C16-5-495-60 & $275 \times 225 \times 4$ & 2.75 & 495 & 60 & 1394 \\
\hline 17 & C17-5-495-60 & $275 \times 225 \times 3.5$ & 2.75 & 495 & 60 & 1343 \\
\hline 18 & $\mathrm{C} 18-5-495-60$ & $275 \times 225 \times 3$ & 2.75 & 495 & 60 & 1289 \\
\hline 19 & $\mathrm{C} 10-3-495-50$ & $225 \times 175 \times 4$ & 1.65 & 495 & 50 & 1180 \\
\hline 20 & C10-3-495-40 & $225 \times 175 \times 4$ & 1.65 & 495 & 40 & 1036 \\
\hline 21 & C10-3-495-30 & $225 \times 175 \times 4$ & 1.65 & 495 & 30 & 884 \\
\hline 22 & C13-4-495-50 & $250 \times 200 \times 4$ & 2.20 & 495 & 50 & 1241 \\
\hline 23 & C13-4-495-40 & $250 \times 200 \times 4$ & 2.20 & 495 & 40 & 1087 \\
\hline 24 & C13-4-495-30 & $250 \times 200 \times 4$ & 2.20 & 495 & 30 & 924 \\
\hline 25 & $\mathrm{C} 16-5-495-50$ & $275 \times 225 \times 4$ & 2.75 & 495 & 50 & 1247 \\
\hline 26 & C16-5-495-40 & $275 \times 225 \times 4$ & 2.75 & 495 & 40 & 1093 \\
\hline 27 & $\mathrm{C} 16-5-495-30$ & $275 \times 225 \times 4$ & 2.75 & 495 & 30 & 931 \\
\hline 28 & $\mathrm{C} 10-3-350-60$ & $225 \times 175 \times 4$ & 1.65 & 350 & 60 & 1157 \\
\hline 29 & C10-3-250-60 & $225 \times 175 \times 4$ & 1.65 & 250 & 60 & 1034 \\
\hline 30 & C13-4-350-60 & $250 \times 200 \times 4$ & 2.20 & 350 & 60 & 1223 \\
\hline 31 & C13-4-250-60 & $250 \times 200 \times 4$ & 2.20 & 250 & 60 & 1095 \\
\hline 32 & C16-5-350-60 & $275 \times 225 \times 4$ & 2.75 & 350 & 60 & 1229 \\
\hline 33 & $\mathrm{C} 16-5-250-60$ & $275 \times 225 \times 4$ & 2.75 & 250 & 60 & 1101 \\
\hline
\end{tabular}

Figure 8 shows the effects of the tapered angle and steel wall thickness on the ductility of the columns. According to the figure, the ductility is significantly influenced by change of the tapered angle. As can be seen from the figure, enhancing the tapered angle from $0^{\circ}$ to $2.75^{\circ}$ increases the ductility of the columns. For instance, by the increase of the tapered angle from $0^{\circ}$ (C1-0-495-60) to $0.55^{\circ}$ (C4-1495-60), $1.10^{\circ}$ (C7-2-495-60), $1.65^{\circ}$ (C10-3-495-60), $2.20^{\circ}(\mathrm{C} 13-4-495-60)$, and $2.75^{\circ}(\mathrm{C} 16-5-495-60)$ the ductility of the columns is improved from 1.827 to $2.664,3.266,4.101,5.172$, and 5.385 , respectively.

Also, the effect of the steel wall thickness on the ductility is illustrated in Figure 8. In accordance with the figure, changing the steel wall thickness noticeably affects the ductility of the columns. By the enhancement of the steel wall thickness from $3 \mathrm{~mm}$ to $4 \mathrm{~mm}$ the ductility of the columns is increased. This point can be due to the fact that increasing the thickness of the steel wall promotes the confinement effect of the steel wall on the concrete core which improves the ductility of the columns. For example, the ductility of the C15-4-495-60 column with the steel wall thickness of $3 \mathrm{~mm}$ is 4.553 , which is improved to 5.172 ductility for the C13-4-495-60 column with steel wall thickness of $4 \mathrm{~mm}$, an increase of $13.6 \%$.

Moreover, it can be seen from Figure 6 that the axial load of the TCFSC columns reduces slowly after the ultimate load, which indicates the favourable ductility in the post-peak stage of the columns.

\subsection{Effect of concrete compressive strength on ultimate axial load capacity}

To investigate the effect of the concrete compressive strength on the ultimate axial load capacity of the columns, various concrete compressive strengths (30 $\mathrm{MPa}, 40 \mathrm{MPa}$, $50 \mathrm{MPa}$, and $60 \mathrm{MPa}$ ) have been also considered in the nonlinear analyses, and their obtained values and curves are illustrated in Table 1 and Figure 9, respectively. As can be perceived from the table and the figure, the ultimate axial load capacity of the columns is considerably affected by change of the concrete compressive strength. The higher concrete compressive strength results in the higher ultimate axial 


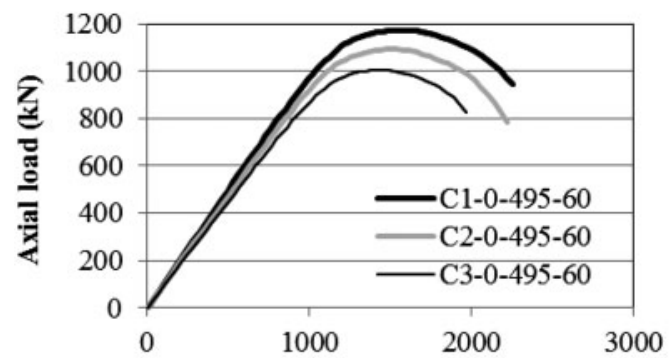

Normalised axial shortening $\Delta / \mathbf{L}\left(\times 10^{\wedge}-6\right)$

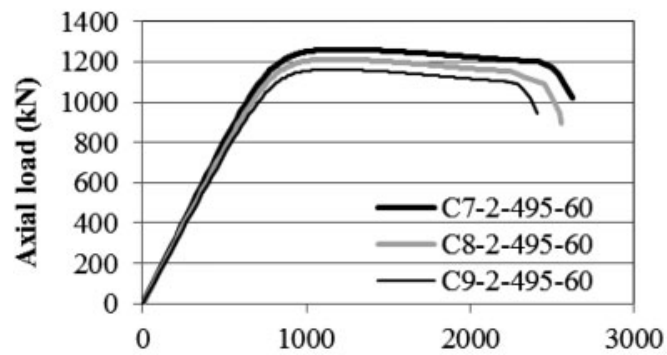

Normalised axial shortening $\Delta / \mathbf{L}\left(\times 10^{\wedge}-6\right)$

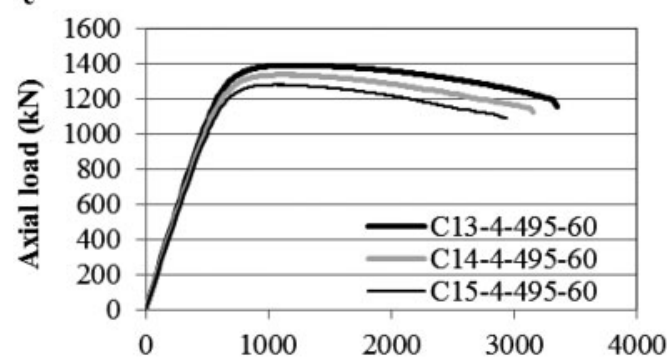

Normalised axial shortening $\Delta / \mathbf{L}\left(\times 10^{\wedge}-6\right)$ b

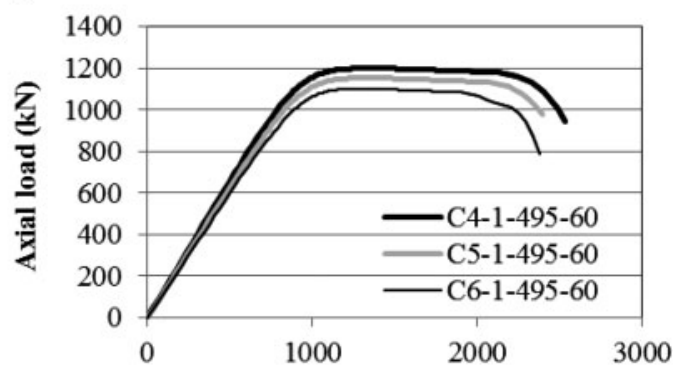

Normalised axial shortening $\Delta / \mathbf{L}\left(\times 10^{\wedge}-6\right)$

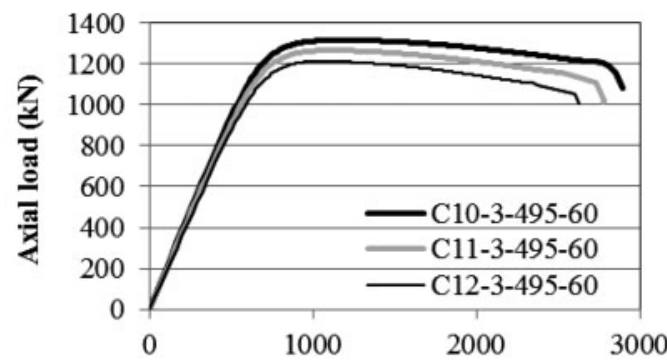

Normalised axial shortening $\Delta / \mathbf{L}\left(\times 10^{\wedge}-6\right)$

f

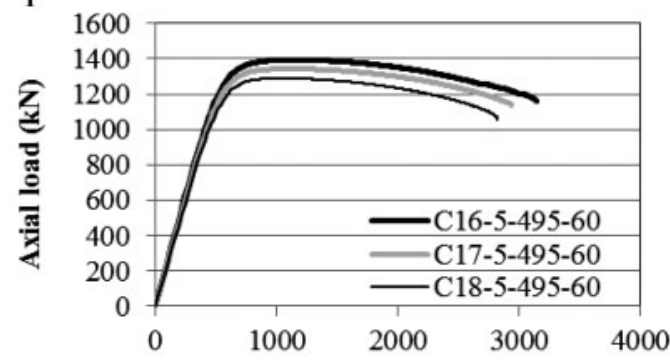

Normalised axial shortening $\Delta / \mathbf{L}\left(\times 10^{\wedge}-6\right)$

Fig. 6. Axial load-normalised axial shortening curves for the columns: (a) $\theta=0^{\circ}$, (b) $\theta=0.55^{\circ}$, (c) $\theta=1.10^{\circ}$, (d) $\theta=1.65^{\circ}$, (e) $\theta=2.20^{\circ}$, (f) $\theta=2.75^{\circ}$

load capacity of the columns. As an example, enhancing the concrete compressive strength of the column C165-495-30 from $30 \mathrm{MPa}$ to $60 \mathrm{MPa}(\mathrm{C} 16-5-495-60) \mathrm{im}-$ proves the ultimate axial load capacity from $931 \mathrm{kN}$ to $1394 \mathrm{kN}$, an increase of $49.7 \%$.

\subsection{Effect of steel yield stress on ultimate axial load capacity}

Nonlinear finite element analyses were also carried out with different steel yield stresses $(250 \mathrm{MPa}$, $350 \mathrm{MPa}$, and $495 \mathrm{MPa}$ ) to examine their effect on the ultimate axial load capacity of the columns. This effect is shown in Figure 10 and their corresponding values are tabulated in Table 1. According to the figure and the table, change of the steel yield stress has a pronounced effect on the ultimate axial load capacity of the columns. By the enhancement of the steel yield stress the ultimate axial load capacity is increased. For instance, if the steel yield stress of the column C13-4$250-60$ is increased from $250 \mathrm{MPa}$ to $495 \mathrm{MPa}(\mathrm{C} 13-4-$
495-60), the ultimate axial load capacity is improved from $1095 \mathrm{kN}$ to $1387 \mathrm{kN}$, an enhancement of $26.7 \%$.

\subsection{Confinement effect}

The steel wall can confine the concrete core, which this effect is crucial in the performance of the composite columns. According to Susantha et al. (2001), Shanmugam and Lakshmi (2001), Johansson (2002), Sakino et al. (2004), and de Oliveira et al. (2009), it is possible to neglect the confinement effect in the first stages of loading, because the Poisson's ratio of concrete is smaller than that of steel. Accordingly, the expansion of the steel wall occurs faster than the concrete core in the radial direction, and the steel wall does not confine the concrete core. At this stage, the steel wall is under compressive stresses and no separation happens between the steel wall and the concrete core. On the other hand, the microcracking of concrete is enhanced, when the load is equal to the uniaxial strength of concrete. At this point, concrete is 

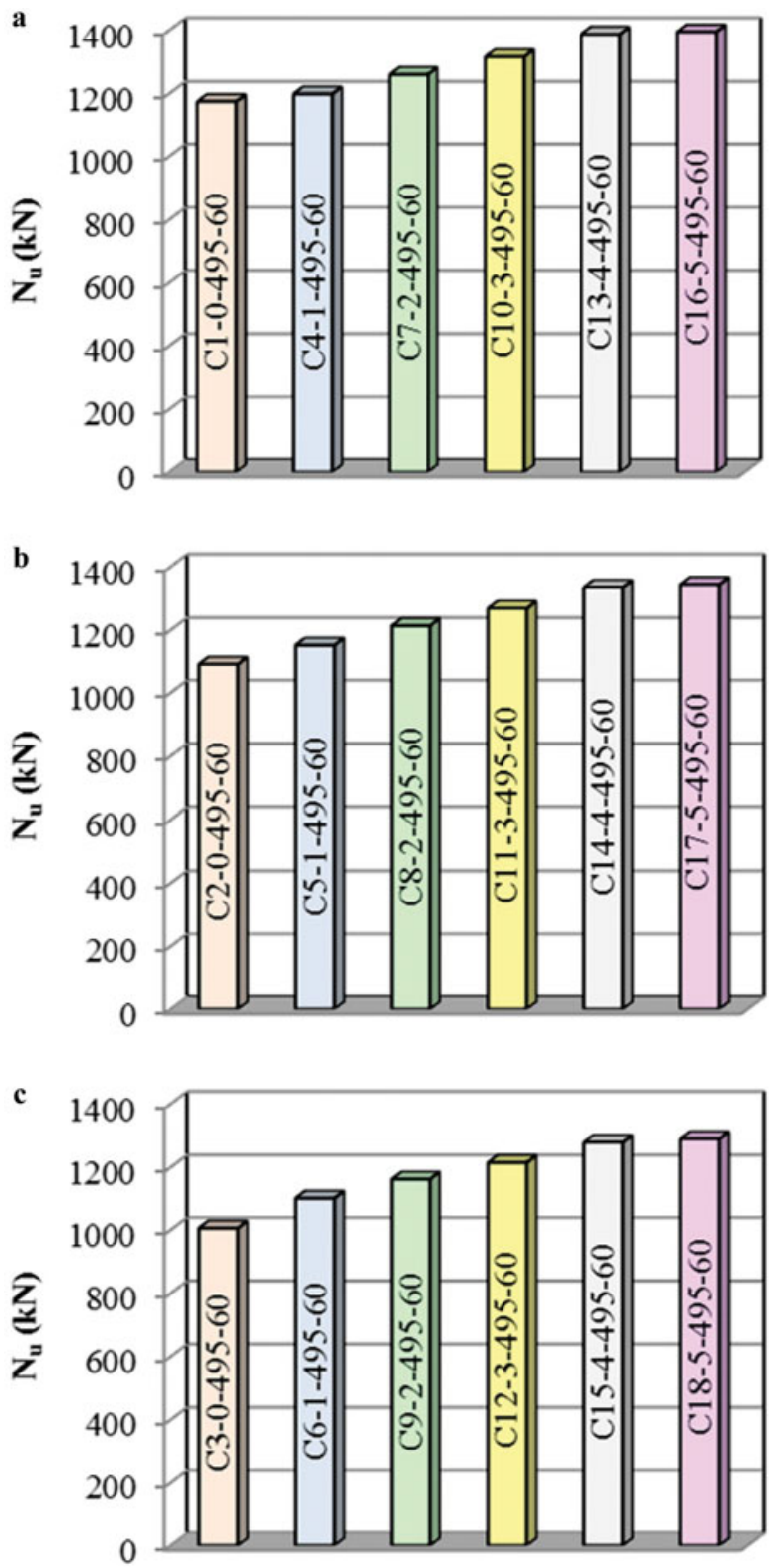

Fig. 7. Effect of tapered angle $\left(\theta=0^{\circ}-2.75^{\circ}\right)$ on ultimate axial load capacity: (a) $t=4 \mathrm{~mm}$, (b) $t=3.5 \mathrm{~mm}$, (c) $t=3 \mathrm{~mm}$

laterally expanded to its maximum level, which results in the efficient confinement provided by the steel wall for the concrete core. Consequently, the ultimate load capacity of the composite columns is higher than the sum of their main components, steel and concrete.

Equation (6) illustrates a confinement factor $(\xi)$ introduced by Han (2001), which can uncover the composite action between the steel wall and the concrete core. This equation is used in this study to investigate the confinement effect of the steel wall on the concrete core of the columns:

$$
\xi=\frac{A_{s} f_{s y}}{A_{c} f_{c k}}
$$

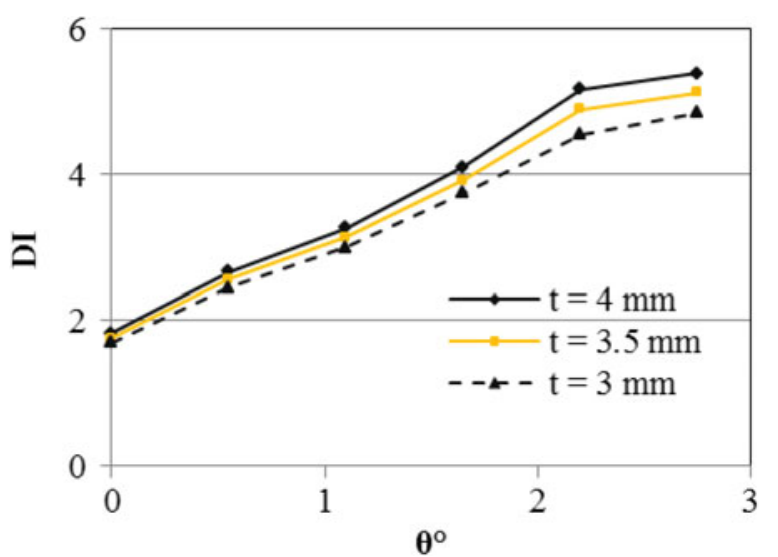

Fig. 8. Effects of tapered angle and steel wall thickness on ductility
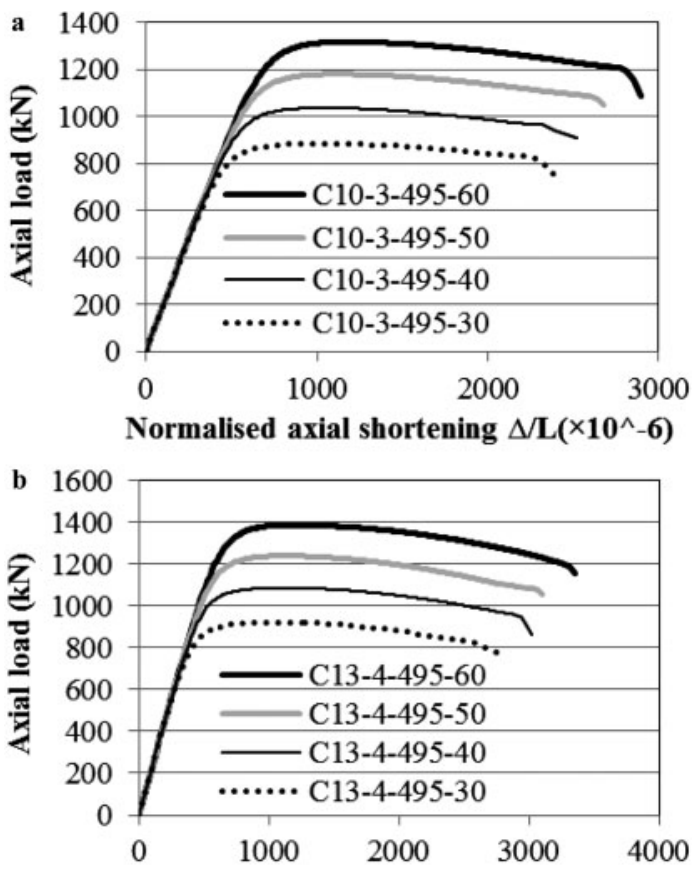

Normalised axial shortening $\Delta / \mathbf{L}\left(\times 10^{\wedge}-6\right)$

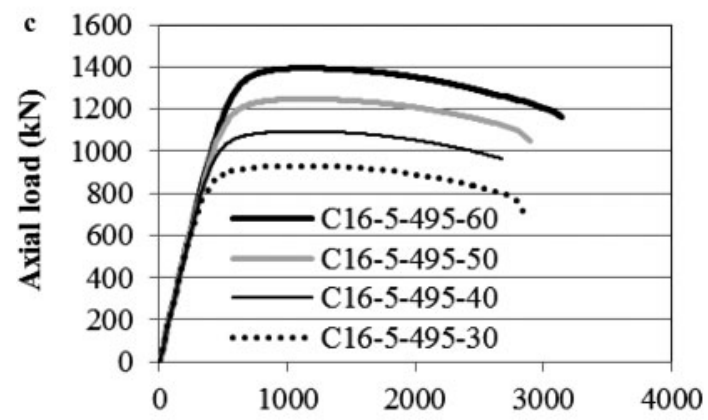

Normalised axial shortening $\Delta / \mathbf{L}\left(\times 10^{\wedge}-6\right)$

Fig. 9. Effect of concrete compressive strength on ultimate axial load capacity $(t=4 \mathrm{~mm})$ : (a) $\theta=1.65^{\circ}$, (b) $\theta=2.20^{\circ}$, (c) $\theta=2.75^{\circ}$ 


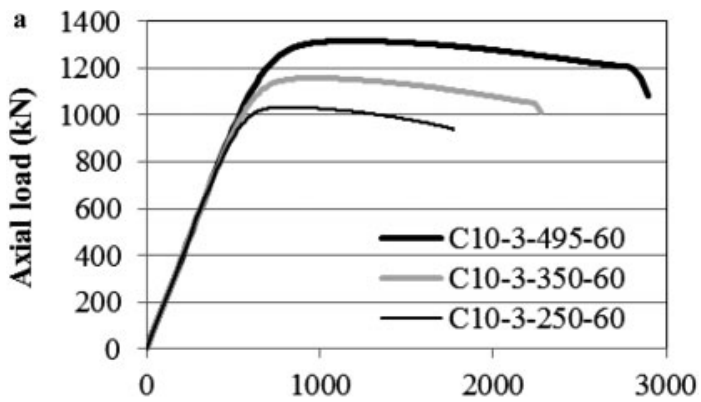

Normalised axial shortening $\Delta / \mathbf{L}\left(\times 10^{\wedge}-6\right)$

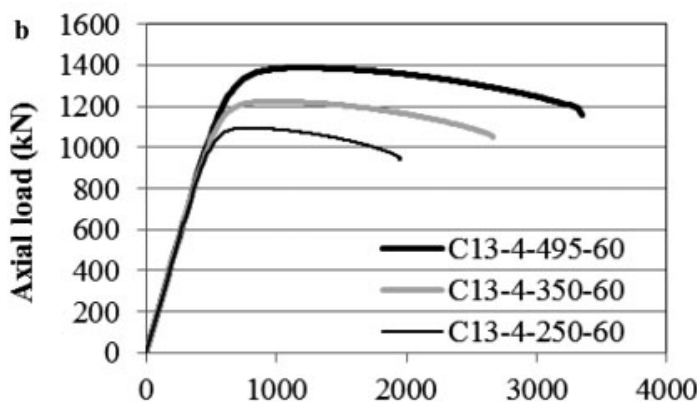

Normalised axial shortening $\Delta / \mathbf{L}\left(\times 10^{\wedge}-6\right)$

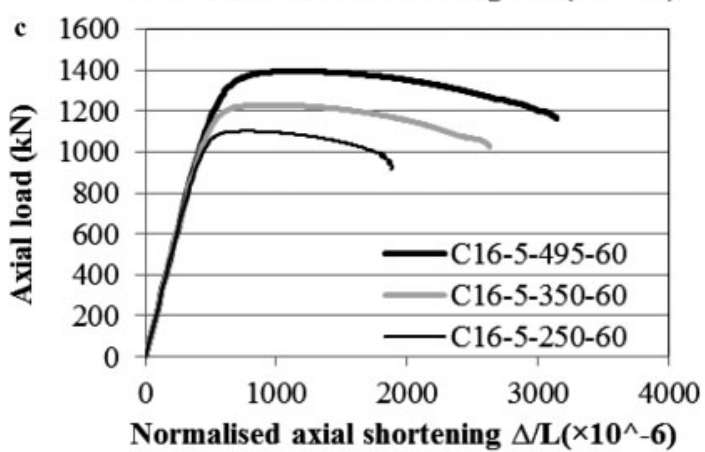

Fig. 10. Effect of steel yield stress on ultimate axial load capacity $(t=4 \mathrm{~mm})$ : (a) $\theta=1.65^{\circ}$, (b) $\theta=2.20^{\circ}$, (c) $\theta=2.75^{\circ}$

where $A_{s}$ and $A_{c}$ are the cross-section areas of the steel wall and the concrete core, respectively and $f_{s y}$ and $f_{c k}$ are the yield stress of the steel wall and $67 \%$ of the cube compressive strength of the concrete core, respectively. According to the corresponding experimental tests of this study done by Liu (2006), the cube compressive

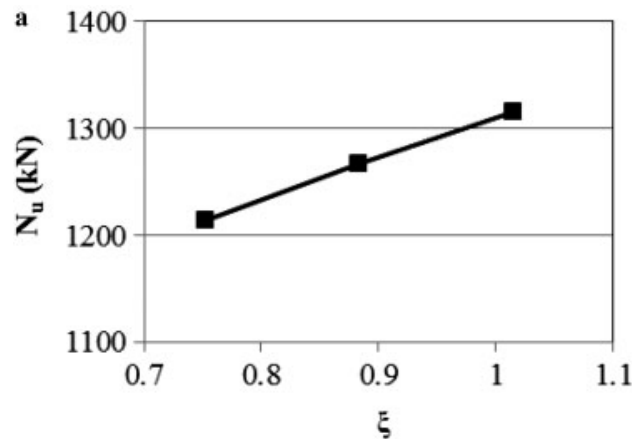

strength of the concrete core has been determined as 73 MPa which is also used in this equation herein. Figure 11 indicates the confinement factor obtained from Eqn. (6) for the typical TCFSC slender columns $\left(\theta=1.65^{\circ} \&\right.$ $t=3 \mathrm{~mm}, 3.5 \mathrm{~mm}$, and $4 \mathrm{~mm}$ ) versus the ultimate axial load capacity and ductility of the columns. Since $A_{s}$ of the TCFSC slender columns is increased from their top and bottom surfaces to their mid-height, $A_{s}$ of the columns considered in Eqn. (6) is the average of $A_{s}$ at their top or bottom surfaces and $A_{s}$ at their mid-height. The same process has been also adopted for $A_{c}$ of the columns. As can be seen from the figure, increasing the steel wall thickness from $3 \mathrm{~mm}$ to $4 \mathrm{~mm}$ enhances the confinement factor, the confinement effect of the steel wall on the concrete core, which leads to the higher ultimate axial load capacity and better ductility of the columns. According to Figure 11(a), enhancement of the steel wall thickness of the column C12-3-495-60 from $3 \mathrm{~mm}$ to $4 \mathrm{~mm}$ of the column C10-3-495-60 increases the confinement factor from 0.752 to 1.015 , which improves the ultimate axial load capacity from $1214 \mathrm{kN}$ to $1316 \mathrm{kN}$, an enhancement of $8.4 \%$. Also, Figure 11(b) illustrates that the same increase of the steel wall thickness and confinement factor for the same columns result in the enhancement of the ductility from 3.743 to 4.101 , an improvement of $9.6 \%$.

\subsection{Failure modes of TCFSC slender columns}

Typical failure modes of the columns are illustrated in Figure 12. In accordance with the figure, the columns showed an overall buckling failure mode with concrete crushing about their mid-height. Local buckling of the steel wall was also observed at the two ends of the columns. In addition, inward buckling of the steel wall did not occur due to the existence of the in-filled concrete. As expected, the increase of the tapered angle led to the decrease of the mid-height deflection of the columns (Fig. 12), which as discussed in the previous sections resulted in the higher ultimate axial load capacity.

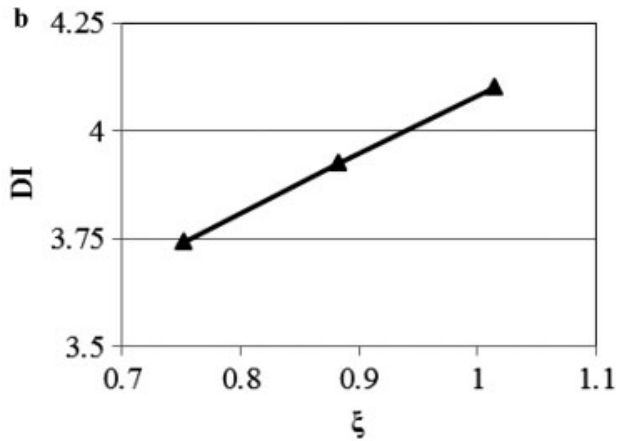

Fig. 11. Confinement effect of steel wall for the columns $\left(\theta=1.65^{\circ} \& t=3 \mathrm{~mm}, 3.5 \mathrm{~mm}\right.$, and $\left.4 \mathrm{~mm}\right)$ : (a) on ultimate axial load capacity, (b) on ductility 

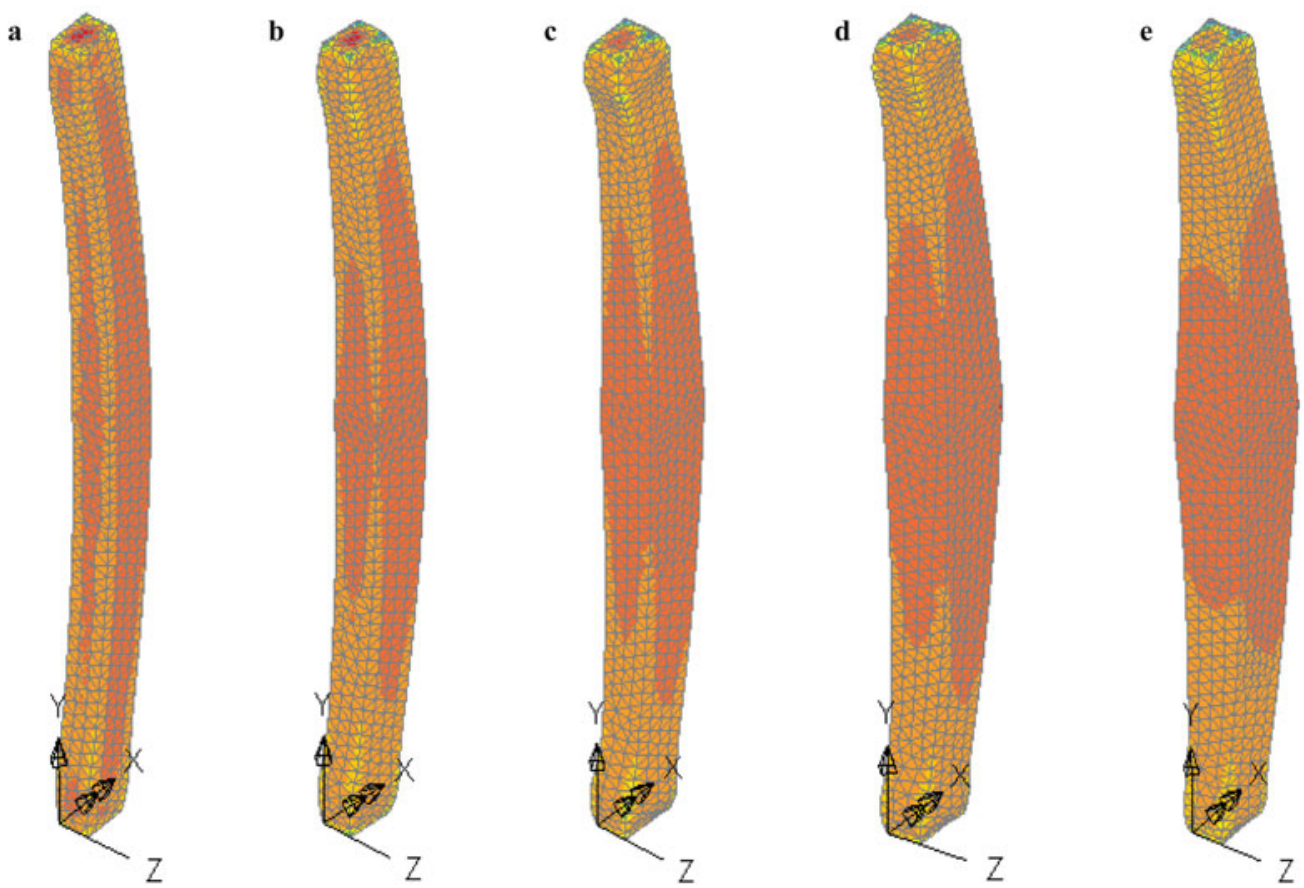

Fig. 12. Typical failure modes of the TCFSC columns: (a) $\theta=0.55^{\circ}$, (b) $\theta=1.10^{\circ}$, (c) $\theta=1.65^{\circ}$, (d) $\theta=2.20^{\circ}$, (e) $\theta=2.75^{\circ}$

\section{Conclusions}

This paper has vastly examined the performance of the axially loaded TCFSC slender columns. These columns are a special kind of tapered composite columns which were formed by the increase of the tapered angle (from $0^{\circ}$ to $2.75^{\circ}$ ) of the tapered composite columns from their top and bottom to their mid-height. The finite element software LUSAS was used for the nonlinear analyses of the columns. The nonlinear finite element results were compared with the existing experimental results, which clearly demonstrated the accuracy of the modelling herein. Nonlinear finite element analyses were further developed to study effects of different parameters, such as various tapered angles, steel wall thicknesses, concrete compressive strengths, and steel yield stresses on the performance of the columns. The results of this study uncovered that these parameters remarkably influence the performance of the columns. Increasing the steel wall thickness significantly enhances the ultimate axial load capacity and ductility of the columns. This improvement of the ultimate axial load capacity and ductility can be because of the point that a thicker steel wall improves the confinement effect of the steel wall on the concrete core, which leads to larger ultimate axial load capacity and better ductility of the columns. Also, the enhancement of the tapered angle of the columns increases the ultimate axial load capacity and ductility of the columns. Moreover, the ultimate axial load capacity of the columns is considerably improved by the increase of the concrete compressive strength. The enhancement of the con- crete compressive strength results in smaller column size, which provides larger usable floor space in a structure. Furthermore, if the steel yield stress is increased, the ultimate axial load capacity of the columns is effectively enhanced. Meanwhile, the confinement effect of the steel wall on the performance of the columns was investigated, which demonstrated that the confinement effect is increased due to the enhancement of the steel wall thickness that offers higher ultimate axial load capacity and ductility of the columns. The failure modes of the columns were identified as overall buckling with concrete crushing about their mid-height. Outward buckling of the steel wall occurred locally at the two ends of the columns. No inward buckling of the steel wall was observed owing to the existence of the concrete infill. These TCFSC columns can be recommended to be practically used in civil projects, where columns need to withstand large loading, because it was revealed that these columns have large ultimate axial load capacity. Also, another practical use of these TCFSC columns can be in regions of high seismicity, where ductility of structures is an important issue since these columns showed to have the advantage of high ductility. Moreover, these TCFSC columns can be a desirable choice from the architectural viewpoint for the construction industry because of their special appearance, which has resulted from their tapered angle.

\section{References}

ACI. 1999. ACI 318-99 Building code requirements for structural concrete and commentary. Detroit, MI, USA: American Concrete Institute. 
Bahrami, A.; Wan Badaruzzaman, W. H.; Osman, S. A. 2011. Nonlinear analysis of concrete-filled steel composite columns subjected to axial loading, Structural Engineering and Mechanics 39(3): 383-398.

Bradford, M. A. 1996. Design strength of slender concretefilled rectangular steel tubes, ACI Structural Journal 93(2): 229-235.

Brauns, J.; Rocens, K. 2004. The effect of material strength on the behaviour of concrete-filled steel elements, Journal of Civil Engineering and Management 10(3): 177-182. http://dx.doi.org/10.1080/13923730.2004.9636304

Dabaon, M.; El-Khoriby, S.; El-Boghdadi, M.; Hassanein, M. F. 2009. Confinement effect of stiffened and unstiffened concrete-filled stainless steel tubular stub columns, Journal of Constructional Steel Research 65(8-9): 1846-1854. http://dx.doi.org/10.1016/j.jcsr.2009.04.012

de Oliveira, W. L. A.; De Nardin, S.; El Debs, A. L. H. C.; El Debs, M. K. 2009. Influence of concrete strength and length/diameter on the axial capacity of CFT columns, Journal of Constructional Steel Research 65(12): 2103-2110. http://dx.doi.org/10.1016/j.jcsr. 2009.07.004

Ellobody, E. 2007. Nonlinear behavior of concrete-filled stainless steel stiffened slender tube columns, ThinWalled Structures 45(3): 259-273. http://dx.doi.org/10.1016/j.tws.2007.02.011

Ellobody, E.; Young, B. 2006a. Design and behaviour of concrete-filled cold-formed stainless steel tube columns, Engineering Structures 28(5): 716-728. http://dx.doi.org/10.1016/j.engstruct.2005.09.023

Ellobody, E.; Young, B. 2006b. Nonlinear analysis of concrete-filled steel SHS and RHS columns, ThinWalled Structures 44(8): 919-930. http://dx.doi.org/10.1016/j.tws.2006.07.005

Ellobody, E.; Young, B.; Lam, D. 2006. Behaviour of normal and high strength concrete-filled compact steel tube circular stub columns, Journal of Constructional Steel Research 62(7): 706-715. http://dx.doi.org/10.1016/j.jcsr.2005.11.002

Finite Element Analysis Ltd. 2006. LUSAS User's Manual, Version 14. UK, Surrey: Finite Element Analysis Ltd.

Giakoumelis, G.; Lam, D. 2004. Axial capacity of circular concrete-filled tube columns, Journal of Constructional Steel Research 60(7): 1049-1068. http://dx.doi.org/10.1016/j.jcsr.2003.10.001

Han, L. H. 2001. Fire performance of concrete filled steel tubular beam-columns, Journal of Constructional Steel Research 57(6): 697-711.

http://dx.doi.org/10.1016/S0143-974X(00)00030-4

Han, L.-H.; Ren, Q.-X.; Li, W. 2010. Tests on inclined, tapered and STS concrete-filled steel tubular (CFST) stub columns, Journal of Constructional Steel Research 66(10): 1186-1195.

http://dx.doi.org/10.1016/j.jcsr.2010.03.014

Han, L.-H.; Ren, Q.-X.; Li, W. 2011. Tests on stub stainless steel-concrete-carbon steel double-skin tubular (DST) columns, Journal of Constructional Steel Research 67(3): 437-452. http://dx.doi.org/10.1016/j.jcsr.2010.09.010

Han, L.-H.; Yang, Y.-F. 2003. Analysis of thin-walled steel RHS columns filled with concrete under long-term sustained loads, Thin-Walled Structures 41(9): 849-870. http://dx.doi.org/10.1016/S0263-8231(03)00029-6
Hu, H.-T.; Huang, C.-S.; Chen, Z.-L. 2005. Finite element analysis of CFT columns subjected to an axial compressive force and bending moment in combination, Journal of Constructional Steel Research 61(12): 1692-1712. http://dx.doi.org/10.1016/j.jcsr.2005.05.002

Hu, H.-T.; Huang, C. S.; Wu, M. H.; Wu, Y. M. 2003. Nonlinear analysis of axially loaded concrete-filled tube columns with confinement effect, Journal of Structural Engineering ASCE 129(10): 1322-1329. http://dx.doi.org/10.1061/(ASCE)0733-9445(2003)129: 10(1322)

Hu, H.-T.; Schnobrich, W. C. 1989. Constitutive modeling of concrete by using nonassociated plasticity, Journal of Materials in Civil Engineering 1(4): 199-216. http://dx.doi.org/10.1061/(ASCE)0899-1561(1989)1: 4(199)

Johansson, M. 2002. Composite action and confinement effects in tubular steel-concrete column: $\mathrm{PhD}$ thesis, Chalmers University of Technology, Goteborg, Sweden.

Lin, M. L.; Tsai, K. C. 2001. Behaviour of double-skinned composite steel tubular columns subjected to combined axial and flexural loads, in Proc. of the First International Conference on the Steel \& Composite Structures, 2001, Pusan, Korea, 1145-1152.

Liu, D. 2006. Behaviour of eccentrically loaded highstrength rectangular concrete-filled steel tubular columns, Journal of Constructional Steel Research 62(8): 839-846. http://dx.doi.org/10.1016/j.jcsr.2005.11.020

Mander, J. B.; Priestley, M. J. N.; Park, R. 1988. Theoretical stress-strain model for confined concrete, Journal of Structural Engineering ASCE 114(8): 1804-1826. http://dx.doi.org/10.1061/(ASCE)0733-9445(1988)114: $8(1804)$

Muciaccia, G.; Giussani, F.; Rosati, G.; Mola, F. 2011. Response of self-compacting concrete filled tubes under eccentric compression, Journal of Constructional Steel Research 67(5): 904-916. http://dx.doi.org/10.1016/j.jcsr.2010.11.003

Mursi, M.; Uy, B. 2003. Strength of concrete filled steel box columns incorporating interaction buckling, Journal of Structural Engineering ASCE 129(5): 626-639. http://dx.doi.org/10.1061/(ASCE)0733-9445(2003)129: $5(626)$

Mursi, M.; Uy, B. 2004. Strength of slender concrete filled high strength steel box columns, Journal of Constructional Steel Research 60(12): 1825-1848. http://dx.doi.org/10.1016/j.jcsr.2004.05.002

Richart, F. E.; Brandzaeg, A.; Brown, R. L. 1928. A study of the failure of concrete under combined compressive stresses. Bull. 185. Champaign, IL, USA: University of Illinois Engineering Experimental Station.

Saenz, L. P. 1964. Discussion of "Equation for the stress-strain curve of concrete" by Desayi, P.; Krishnan, S., Journal of the American Concrete Institute 61(3): 1229-1235.

Sakino, K.; Nakahara, H.; Morino, S.; Nishiyama, A. 2004. Behavior of centrally loaded concrete-filled steel-tube short columns, Journal of Structural Engineering ASCE 130(2): 180-188. http://dx.doi.org/10.1061/(ASCE)0733-9445(2004) 130:2(180) 
Shanmugam, N. E.; Lakshmi, B. 2001. State of the art report on steel-concrete composite columns, Journal of Constructional Steel Research 57(10): 1041-1080. http://dx.doi.org/10.1016/S0143-974X(01)00021-9

Shanmugam, N. E.; Lakshmi, B.; Uy, B. 2002. An analytical model for thin-walled steel box columns with concrete in-fill, Engineering Structures 24(6): 825-838. http://dx.doi.org/10.1016/S0141-0296(02)00019-6

Susantha, K. A. S.; Ge, H. B.; Usami, T. 2001. A capacity prediction procedure for concrete-filled steel columns, Journal of Earthquake Engineering 5(4): 483-520.

Tao, Z.; Uy, B.; Han, L.-H.; Wang, Z.-B. 2009. Analysis and design of concrete-filled stiffened thin-walled steel tubular columns under axial compression, ThinWalled Structures 47(12): 1544-1556. http://dx.doi.org/10.1016/j.tws.2009.05.006

Tomii, M. 1991. Ductile and strong columns composed of steel tube infilled concrete and longitudinal steel bars. Special volume, in Proc. of the Third International Conference on Steel-concrete Composite Structures, 1991, Association of Steel-Concrete Structures, Fukuoka, Japan.
Uenaka, K.; Kitoh, H.; Sonoda, K. 2010. Concrete filled double skin circular stub columns under compression, Thin-Walled Structures 48(1): 19-24. http://dx.doi.org/10.1016/j.tws.2009.08.001

Young, B.; Ellobody, E. 2006. Experimental investigation of concrete-filled cold-formed high strength stainless steel tube columns, Journal of Constructional Steel Research 62(5): 484-492. http://dx.doi.org/10.1016/j.jcsr.2005.08.004

Yu, Q.; Tao, Z.; Wu, Y.-X. 2008. Experimental behaviour of high performance concrete-filled steel tubular columns, Thin-Walled Structures 46(4): 362-370. http://dx.doi.org/10.1016/j.tws.2007.10.001

Zeghiche, J.; Chaoui, K. 2005. An experimental behaviour of concrete-filled steel tubular columns, Journal of Constructional Steel Research 61(1): 53-66. http://dx.doi.org/10.1016/j.jcsr.2004.06.006

Zhang, S.; Guo, L. 2007. Behaviour of high strength concrete-filled slender RHS steel tubes, Advances in Structural Engineering 10(4): 337-351. http://dx.doi.org/10.1260/136943307783239381

\begin{abstract}
Alireza BAHRAMI. PhD student at the Department of Civil and Structural Engineering, Universiti Kebangsaan Malaysia (UKM), Bangi, Selangor, Malaysia since 2009 to date. BEng in Civil from Bushehr Islamic Azad University in 1998. MSc in Civil and Structural Engineering with an excellent grade from Universiti Kebangsaan Malaysia (UKM) in 2009. Fourteen years of industrial experience in Civil Engineering. Lecturer at some universities in Iran. Scientific interests: steel-concrete composite structural elements and their behaviour, and also engineering software for structural elements analysis.
\end{abstract}

Wan Hamidon WAN BADARUZZAMAN. Professor at the Department of Civil and Structural Engineering, Universiti Kebangsaan Malaysia, Bangi, Selangor, Malaysia. PhD in Structural Engineering from the University of Wales, Cardiff, U.K. in 1994. Twenty-six years of vast teaching, training, research, publication, administration, accreditation, and consultancy experiences. On secondment, was the Chief Executive Officer of the UKM Perunding Kejuruteraan \& Arkitek Sdn. Bhd., a university professional consultancy company. Scientific interests: steelconcrete composite structural elements, light weight cold-formed composite structures, and their behaviour.

Siti Aminah OSMAN. Senior lecturer at the Department of Civil and Structural Engineering, Universiti Kebangsaan Malaysia (UKM), Bangi, Selangor, Malaysia. A member of Board of Engineers Malaysia (BEM). Graduated from Universiti Teknologi Malaysia in 1992 with BEng (Hons), MSc in Structural Engineering from University of Bradford, U.K. in 1995 and PhD in Civil and Structural Engineering from Universiti Kebangsaan Malaysia (UKM) in 2006. After undergraduate studies, started teaching as a lecturer at Universiti Kebangsaan Malaysia (UKM). Scientific interests: structural engineering, wind engineering, and industrial building system (IBS) construction. 